\title{
Murine TYRP2 Plasmid DNA Vaccine
}

National Cancer Institute

\section{Source}

National Cancer Institute. Murine TYRP2 Plasmid DNA Vaccine. NCI Thesaurus. Code C77877.

A plasmid DNA vaccine encoding the mouse tumor associated antigen tyrosinase-related protein-2 (TYRP2) with potential immunostimulating and antineoplastic activities. Upon administration, murine TYRP2 plasmid DNA vaccine may stimulate the host immune system to mount a cytotoxic T lymphocyte $(C T L)$ response ag ainst tumor cells expressing TYRP2; this vaccine may also induce an immune response against tyrosinaserelated protein-1 (TYRP1). TYRP2 and TYRP1, melanosomal membrane glycoproteins upregulated in melanoma cells, are involved in melanin synthesis. 